\title{
Dialectical Analysis of Global Staffing Policy
}

\author{
Weidan Zhang \\ University of Glasgow, Glasgow G12 8QQ, UK \\ Email: raisedan@163.com
}

\begin{abstract}
Global staffing is an essential aspect of human resource management in multinational corporations (MNC) (Collings \& Scullion, 2009). As the positioning of multinational organizations gradually becomes global, multinational companies must cultivate suitable global personnel. Flexible and adequate staffing and management skills can give transnational corporations a particular competitive advantage in global operations (Collings \& Scullion, 2009). Understanding the background of the local market and gaining and sharing tacit knowledge in jobs around the world are all necessary professional skills for the multinational company (Harvey et al., 1999). However, human resources management departments also face more significant challenges as the multinational company expands its business globally. Learning how to effectively respond to the staffing problems of multinational companies in the course of operation reflects the company's operating capabilities. This article will first define and elaborate the global staffing policy, while the factors that will make the system more effective will be introduced. Secondly, the current problems and challenges faced by multinational companies will be listed, followed by corresponding measures. Finally, other recommendations will be provided in some areas for the human resources of multinational companies.
\end{abstract}

Keywords: global staffing, multinational corporations, differentiation, integration

\section{Global staffing policy}

\subsection{Definition and interpretation}

The global staffing policy is often used as an indicator of the overall IHRM strategy. It is defined as the issue of multinational companies hiring parent country nationals (PCNs), host country nationals (HCNs) and third-country nationals (TCNs) to fill vacancies in critical positions at head offices and subsidiaries (Sparrow, 2007; Tarique \& Schuler; 2008).

PCNs (parent country nationals) are employees of an organization, and they are the citizens of the country where a multinational company's foreign subsidiary is located (Tarique \& Schuler, 2008). HCNs (host country nationals) are citizens of the country where the MNC's headquarters are located (Tarique \& Schuler, 2008). They are employees of multinational corporations. Previous studies have shown that as HCNs, they should have the essential ability to be familiar with the corporate culture of a multinational company, and they must have the ability to maintain the monitoring of subsidiary operations and maintain effective communication with the headquarters company (Borg \& Harzing, 1995). TCNs (thirdcountry nationals) are neither nationals of the country where the multinational company is headquartered nor citizens of the country where the host country's subsidiary is established (Tarique \& Schuler; 2008). For these three types of nationals, being familiar with and understanding the political, economic, legal and cultural background ofthe countries where the parent companies and subsidiaries of multinational companies are located helps to conduct business.

The global staffing area has grown considerably in the past decade, which reflects the importance that multinational companies or organizations place in the field of international human resources management (Collings et al., 2009). For example, Collings, Scullion and Dowling (2009) mentioned that research around the global staffing problem had increased significantly in recent years. They stated that the proper combination of national employees in these three places could help multinational companies to realize their ability to learn and integrate innovation, which has a significant impact on the development of multinational companies (Collings et al., 2009).

Some scholars have also studied and further expanded their thinking on global staffing. For example, other types of international employees, including short-term and long-term expatriates, global managers, etc. are explored (Briscoe \& Schuler, 2004). Global staffing policy also pays attention to factors such as the level of cultural differences between headquarters and subsidiaries, host country political risks, different education levels, and cost of living at the same time (Sparrow, 2007). However, the research in the field of global staffing is still relatively new and in a dynamic and evolving situation (Collings \& Scullion, 2009). Global employees play a crucial role in strategic international human resource management, especially in innovation, organizational learning, and corporate integration (Collings \& Scullion, 2009). 


\subsection{Factors contributing to an effective global staffing policy}

The framework of strategic international human resources management provides several aspects that affect the management effectiveness of multinational companies (Schuler et al., 1993). Factors contributing to an effective global staffing policy will be analyzed in the perspective of exogenous characteristics, endogenous characteristics, inter-unit linkages and internal operations.

\subsubsection{Exogenous characteristics}

The first factor is the mastery of the overall characteristics of the host country by the human resources department and its countermeasures. This process involves understanding the macro environment of a nation and region. The host country has a different political (e.g. union system), economic (economy development and potential risks), and legal (labour law) background compared with the country where the multinational company's headquarters is located, especially the changing dynamically economic situation, which increases the complexity of macro background analysis of host country (McNulty $\&$ Cieri, 2011). Besides, there may be political, economic, and legal differences in different regions within the host country. For example, in the UK, there are institutional differences between Scotland and England (Hunter, 2020). HR should develop a suitable international strategy based on the local background information of the host country in order to achieve effective staffing.

Another factor is the human resources department's mastery and familiarity with the characteristics of multinational companies1 industries, including different departments and business types (McNulty \& Cieri, 2011). For example, for a company that produces fast-moving consumer products such as Unilever, more and more young consumers are pursuing higher quality product values these days, they value the sustainability and environmental protection of their products (Hunter, 2020). As for companies in the manufacturing industry may be significantly affected by fluctuations in market demand, market demand will have an impact on global personnel strategies (McNulty \& Cieri, 2011). For example, the need for expatriate employees in some regions may decrease or increase due to product demand. When HR is deployed, it should consider the relevant background of talents required by the industry to match the needs of the industry in order to deal with the pressure brought by the industry (McNulty \& Cieri, 2011).

\subsubsection{Endogenous characteristics}

Multinational companies have a clear international business structure and an international division of labour structure. In international business, multinational corporations have added a unit group or organization to handle the international division of labour (Schuler et al., 1993). Researchers have shown that after critical decisions are made at the headquarters, the subsidiaries are also disseminated and developed accordingly (Schuler et al., 1993). International human resources decision-making should choose foreign personnel who understand global operations for strategic analysis of subsidiaries. At the same time, researchers also mentioned that the use of appropriate organizational structure forms, such as mixed structure forms, can effectively serve local needs (Schuler et al., 1993).

Proper management of the international human resources department in terms of recruitment, training and compensation is more able to deal with the diversity and complexity of multinational companies 1 problems (Schuler et al., 1993). The success of expatriate missions is based on effective recruitment and selection (Collings et al., 2007).

People with rich knowledge and experience in the operation or management of international companies are betterqualified to work for multinational companies. In addition, cross-cultural training and exchanges help expatriates become more familiar with local cultural backgrounds and conduct related business processes. Collings et al, (2007) have also pointed out that cultural awareness and cross-cultural communication training are essential factors that MNC considers in its operations. Concerning remuneration, it is necessary to provide expatriates with the required salary incentives or subsidies, given the challenges that the cost of living in the host country may differ from the home country, such as the cost of temporary housing (Collings et al., 2007).

\subsubsection{Inter-unit linkages}

The correct differentiation and integration model adopted by multinational companies is a valuable means to achieve efficient global staffing. Multinational operating companies should formulate differences and integration models based on the inherent characteristics of the host countries, so as to meet local needs based on market conditions (Schuler et al., 1993). In this process, the parent company needs to provide the necessary expertise and skills to the subsidiary to help the subsidiary make a strategy that better meets the market (Collings et al., 2009). For example, Unilever designed a smaller shampoo container specifically for Indian consumers to cater to local market needs and make regionally differentiated designs for its products (Hunter, 2020). This complements the direction of Unilever's brand competition, seeking competitive advantages for multinational companies through high-quality and unique brand products. The differentiation or integration of the brand will affect the deployment of personnel in the human resources department. 


\subsubsection{Internal operations}

The human resources department's focus on overall corporate strategic issues has led to effective global staffing. International HR practitioners start from the strategy of multinational companies to ensure that each unit operates effectively to the maximum extent possible (Schuler et al., 1993). In multinational business, the parent company and each subsidiary should take political, legal, economic, cultural and other local social background factors into consideration in their operations. At the same time, global employees play a potential role in organizational learning and innovation in operation (Schuler et al., 1993). Learning and innovation of internal knowledge can enable the company to obtain the latest information on a worldwide scale in order to continue to maintain and improve the competitiveness of its products and services in the industry.

\section{Challenges faced by HR of MNCs and possible countermeasures}

Human resources management practitioners of multinational companies face the challenge of diversifying their operations in a global environment. There is complexity in implementing effective staffing systems internationally (Wiechmann et al., 2003).

\subsection{Culture difference}

Cultural differences challenge businesses related to global staffing. Some expatriate employees who are dispatched from the parent company to the subsidiary company face the cultural shock of the host country, such as language barriers, different living habits, different ways of speaking or ways of doing things (Abugre, 2017). They may not adapt to the culture of the host country quickly in a short period due to these factors.

Researchers have found that cross-cultural training helps expatriates improve their international business (Abugre, 2017). Cross-cultural training provides expatriates with an opportunity to understand the local environment and culture. After receiving the training, expatriates are able to establish a good rapport with local employees, which reduces barriers to communication and understanding and further improves work efficiency (Abugre, 2017). Some trained interviewees stated that cross-cultural training enhanced their own knowledge and development and which the experience, in turn, promoted their work and customer service efficiency (Abugre, 2017). Other expatriates suggested that cross-cultural training should be universally available to everyone who is assigned, as this is very effective. Expatriates do not have to spend months figuring out how locals do things (Abugre, 2017).

Another possible way to overcome cultural differences is to establish organizational values. Among them, trust is one of the fundamental values that multinational companies should possess. For example, Agilent's regional managers have stated that faith built between members and members within a multinational company can overcome many cultural differences that hinder the development of global staffing policy (Wiechmann et al., 2003).

\subsection{Challenges about expatriate assignment}

Many MNCs managers consider it is essential to get a return on investment (ROI) from expatriates, while there are risks and uncertainties in talent deployment. McNulty and Tharenou (2004) defined expatriate ROI: 'A calculation in which the financial and non-financial benefits to the firm are compared with the financial and non-financial costs of the international assignment, as appropriate to the assignment's purpose. 1 This definition relates to the benefits of global staffing decisions to the costs incurred by a multinational

corporation and also used to track the return on investment in key talent allocation (McNulty, 2009). Regarding the risks faced by expatriates, for example, the process of global staffing can incur huge costs, especially for long-term expatriate assignments. McNulty et al, (2009) pointed out that the cost of expatriates might include difficulties in employee relations, weaker psychological contracts and reduced commitments, or other stress. Collings et al. (2007) also mentioned that the cost of expatriation failure is higher, including direct costs (e.g. the salaries of expatriates, training costs related to various expatriates and travel expenses) and indirect costs (e.g. potential loss of market share in the host country). The success or failure of the assignment is related to the reputation of the multinational company. Negative expatriate assignments will damage the reputation of the company and affect its business prospects in the host country (Collings et al., 2007).

Some scholars have proposed that on the issue of global staffing, multinational companies can use the model of expatriate return on investment to test the performance of expatriates (Collings et al., 2007). This theoretical model of expatriate investment return on investment was proposed by McNulty and Tharenouti (2004). The model pays more attention to the monitoring of the business performed by the expatriates and effectively evaluates the effectiveness of the expatriate tasks. This can help human resource managers to carry out an analysis of costs and benefits (Collings et al., 2007). Collings et al, (2007) evaluated that the study of return on investment provided a useful model for the human resources of multinational companies, which can better determine the return rate of expatriate assignment costs. 


\subsection{Inconsistent evaluation methods of expatriates}

A certain number of expatriates are treated to evaluate their business by using inconsistent evaluation methods (McNulty, 2009). Studies show that most global managers say they work in an environment where information may be limited, and performance metrics are not uniform, what is more time and resources may limit their pursuit of the best candidate (McNulty, 2009). For example, the education standards of the host country may differ from the home country. This has undoubtedly increased difficulties in global staffing. Therefore, for multinational companies, the management of expatriates and other relative staff should adopt an expatriate ROI assessment standard that is compatible with the company's cultural background (McNulty, 2009). Meanwhile, selecting a systematic approach to manage the internal resource (McNulty, 2009).

\subsection{Career issues}

In the contemporary international context, the changing nature of occupations has also become one of the challenges faced by international human resources in treating global staffing (Collings, 2007). Changes in personnel's professional attitudes may affect the willingness to accept tasks or the completion of tasks. With the development of the labour market, more and more talents attach great importance to professional mobility, and they may reduce their contribution and investment to a specific organization (Collings, 2007). International expatriates are paying more and more attention to personal career development values and prospects, such as whether the value created by themselves is indeed recognized and valued by organizations (Collings, 2007).

As a multinational company, it is necessary to create visible career development prospects for employees. While ensuring the basic employment security, organizations should also improve their employ ability in the labor market and ensure that employees' own experience and capabilities develop (Collings, 2007). At the same time, in the process of employee employment, psychological contracts should be established reasonably to ensure employee loyalty and improve their self-confidence and work efficiency (McNulty, 2011).

\section{Conclusion}

This article is mainly focused on the global staffing issues faced by multinational companies. After introducing the definition of global staffing, the factors that contribute to effective global staffing are analyzed from four aspects (exogenous characteristics, endogenous characteristics, inter-unit linkages, internal operations). International human resources 1 familiarity with the host country and local industry backgrounds of multinational companies helps to facilitate effective global staffing. At the same time, it is necessary to build an internal organizational structure and take appropriate management methods. Adopting the correct differentiation and integration model and focusing on overall corporate strategic issues are also factors in achieving this goal. The second half of the article tells about the challenges faced by human resources of multinational companies including culture difference, challenges about the expatriate assignment, inconsistent evaluation methods and career issues, some corresponding solutions are suggested. In general, the global staffing problem is characterized by complexity and diversity, and international human resources should appropriately and cautiously handle the business problems of multinational companies based on a variety of information backgrounds.

\section{Reference}

[1] Abugre, J.B. Cross-cultural staffing in Ghana. In: Wintersberger, D. ed. International Human Resource Management: A case study approach. London: Kogan Page; 2017.

[2] Borg, M. \& Harzing, A. Composing an International Staff. International Human Resource Management, eds. A. Harzing and J. Van Ruysseveldt. London: Sage; 1995.

[3] Briscoe, D. \& Schuler, R. International Human Resource Management: Policies \& Practices for the Global Enterprise. 2nd ed. New York: Routledge; 2004.

[4] Collings, D.G., Scullion, H. \& Morley, M.J. Changing patterns of global staffing in the multinational enterprise: Challenges to the conventional expatriate assignment and emerging alternatives. Journal of World Business. 2007; 42(2): 198-213.

[5] Collings, D.G. \& Scullion, H. Global staffing. The International Journal of Human Resource Management. 2009; 20(6): 1249-1252.

[6] Collings, D.G., Scullion, H. \& Dowling, P.J. Global staffing: a review and thematic research agenda. The International Journal of Human Resource Management. 2009; 20(6): 1253-1272.

[7] Hunter, P. International Human Resource Management. Auxiliary case for lecture, at the University of Glasgow; 2020.

[8] McNulty, De Cieri, H. \& Hutchings, K. Do global firms measure expatriate return on investment? An empirical exam- 
ination of measures, barriers and variables influencing global staffing practices. The International Journal of Human Resource Management. 2009; 20(6): 1309-1326.

[9] McNulty, Y. \& Cieri, H.D. Global Mobility in the 21st Century: Conceptualising Expatriate Return on Investment in Global Firms. MIR: Management International Review. 2011; 51(6): 897-919.

[10] Tarique, I. \& Schuler, R. Emerging issues and challenges in global staffing: a North American perspective. The International Journal of Human Resource Management. 2008; (19)8: 1397-1415.

[11] Schuler, R. S., Dowling, P. J. \& De Cieri, H. An integrative framework ofstrategic international human resource management. The International Journal of Human Resource Management. 1993; 4(4): 717-764.

[12] Sparrow, P. R. Globalization of HR atfunction level: four UK-based case studies ofthe international recruitment and selection process. The International Journal of Human Resource Management. 2007; 18(5): 845-867.

[13] Wiechmann, D., Ryan, A.M. \& Hemingway, M. Designing and implementing global staffing systems: Part 1 — Leaders in global staffing. Human Resource Management. 2003; 42(1): 71-83.

[14] McNulty, Y. \& Tharenou, P. Expatriate Return on Investment: A Definition and Antecedents. Journal of International Studies of Management and Organization. 2004; 34: 68-95. 